\title{
Ethno-veterinary medicine: A potential alternative to animal health delivery in Wolmera district, Oro- mia Region, Ethiopia
}

\author{
Yohans Abera ${ }^{1}$ and Belay Mulate ${ }^{1 *}$ \\ 1 School of Veterinary Medicine Wollo University P.O.Box 1145, Ethiopia \\ *Corresponding author: Belay M, Email: dorogibir@gmail.com
}

\begin{abstract}
This survey was conducted from December 2016 to March 2017 in Wolmera district of Oromia Region, Ethiopia to document indigenous knowledge of the community on plants used in ethno-veterinary medicine. From a total 80 respondents from eight peasant associations, 48 respondents were selected purposely by the researcher alone while the rest 32 were selected purposely by the help of local elders in the study area. Majority of respondents $63(87.27 \%)$ were male and the remained $17(12.72 \%)$ were females. Most of the respondents 55(68.75\%) were used plants to treat livestock ailment, and $50(91 \%)$ acquired the knowledge from their parents and elders of blood relationship. Twenty- five medicinal plant species of veterinary importance classified into 22 families were documented. From identified plant families, asteraceae, euphorbiacea, solonaceae and polygonaceae were represented by 2 species each. The remaining (17 families) were represented by single plant species. Leaves were the most frequently utilized plant part (68\%) and oral route $(80 \%)$ was the most common route of administration, whereas concoction (60\%) accounted the major form of preparation of herbal remedies. Determination of the dose is done by using different household utensils and also by using their own hand. Anthrax, black leg, ecto and endo parasites, rabies, foot and mouth disease, bloat, and colic were among the fifteen different livestock diseases or syndromes treated by traditional practitioners. Fifty-five out of 80 respondents who participated in this survey have an awareness on ethnoveterinary practice but plant parts used, dose and routes of administration were varies among the traditional practitioners. Therefore, we strongly recommended for detail scientific and pharmacological evaluations (efficacy, safety, mode of delivery and dosage) of the identified plant species in future use.
\end{abstract}

Key words: Aliments; Endogenous knowledge; Ethno veterinary; Medicinal plants 


\section{Introduction}

Absence or inaccessibility to modern veterinary services and high cost of modern drugs, as well as failure in their efficacy, a large proportion of farmers rely on traditional medicine (herbal remedies) to keep their livestock healthy and productive for several decades (Kaur et al., 2011). In Ethiopia, due to huge potential of medicinal plants, traditional herbal medicine is an integral part of the local culture and used widely for the treatment of human and livestock aliments (Giday and Teklehaymanot, 2013).

Ethno-veterinary knowledge like other traditional knowledge is transferred from generation to generation through the word of mouth (oral tales) with great secrecy through family members, horizontally by exchange through peers, or diagonally through traditional healers to learners (Yirga et al., 2012). This knowledge may disappear because of rapid socio-economic and technological changes. Moreover, environmental degradation, agricultural expansion (cultivation of marginal lands) and urbanization warranting urgent need to document and preserve the indigenous knowledge (Kalayou et al., 2012; Khan et al., 2012)

For the sake of documentation of endogenous knowledge regarding ethnoveterinary medicinal plants, several studies have been conducted throughout the world such as in South Africa (Vander and Swan, 2001), in Zimbabwe(Tafara and Taona, 2004), in China ( Shen et al.,2010),in Pakistan (Deeba et al., 2009) and in India (Somvanshi,2006). Similarly, in Ethiopia, studies have been conducted on plant remedies which are used extensively by animal owners to treat livestock diseases (Giday and Ameni, 2003; Hunde et al., 2004; Kebu et al., 2004; Sori et al., 2004; Yineger et al.,2007; Yineger et al., 2008; Yigezu et al., 2014). However, the effort is still quite insignificant when compared to the undocumented ethnoveterinary plant lore of the country. Therefore, the present study was conducted to identify and document plants used in ethnoveterinary practices along with livestock ailments treated by farmers in Wolmera district of Oromia Region, Ethiopia. 


\section{Materials and Methods}

\section{Study area}

This study was conducted from December 2016 to March 2017 in eight selected peasant associations (PAs) of Wolmera District of Oromia Region, Ethiopia. The district is located at a distance of $33 \mathrm{~km}$ West of the capital, Addis Ababa at latitude $9^{\circ} 3^{\prime} \mathrm{N}$ and $38^{\circ} 30^{\prime} \mathrm{E}$ longitude (Fig 1). The district is largely a highland area. The highest point in this district is mount Wechecha with an elevation of 3191 m.a.s.l, located in the southern part of the district. The Menagesha National forest (2500 hectares in size) covers the southern and western slopes of this mountain (Briggs, 2002). The average annual rainfall of the district is $1014 \mathrm{~mm}$. The maximum and minimum temperatures of the area are $22.3^{\circ} \mathrm{C}$ and $6.16^{\circ} \mathrm{C}$, respectively; and the area experiences a bimodal rainfall patterns with a short rainy season which occurs from March to May and long rainy season which starts at the end of June and ends at early November. Oromiffa is spoken as a first language by $70.1 \%$ of the residences, whereas $24.22 \%$ spoke Amharic and the remaining 5.68\% spoke other languages. Crop-livestock farming system is being practiced in the district and the dominant livestock raised in the district is cattle, small ruminants and equines in their decreasing order (CSA, 2015).

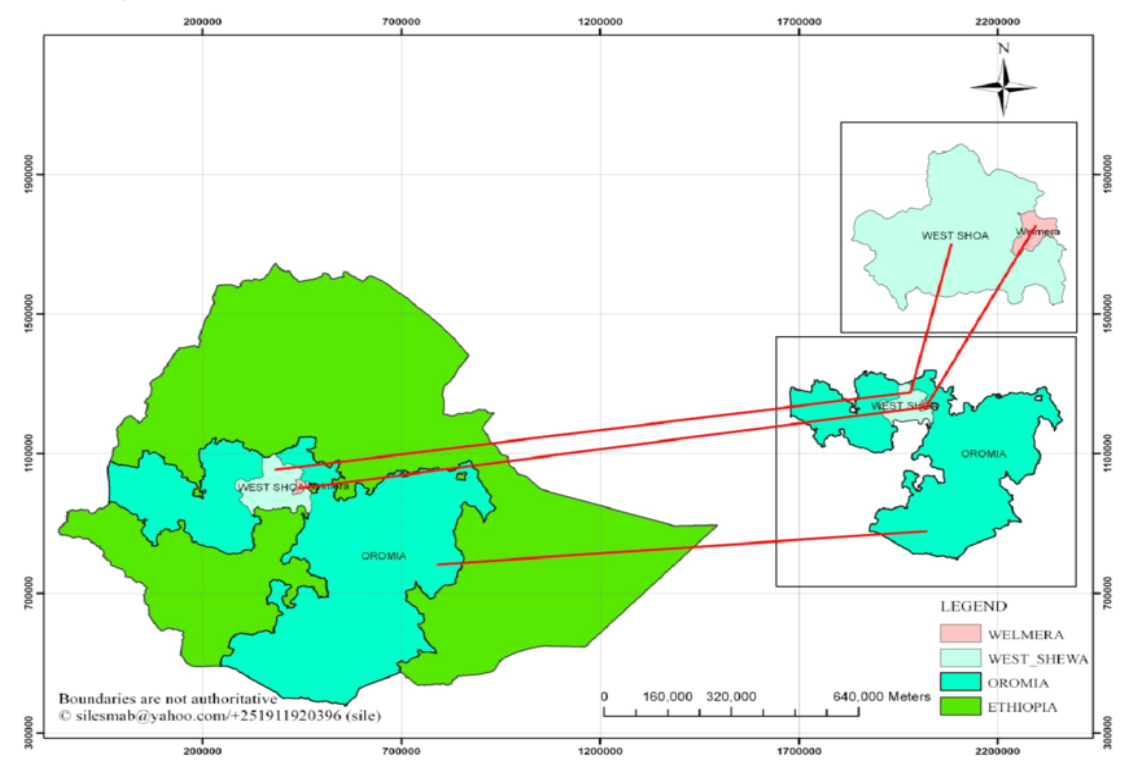

Figure 1. Map of the study district 


\section{Study design}

A community based cross-sectional study design supported by questionnaire and close observation was conducted to collect Ethno-veterinary knowledge on medicinal plants in the selected peasant associations. A semi-structured questionnaire was prepared and administered to 80 respondents who depended on plant recourses for managing livestock aliments and showed interest to participate in the study. From the total respondents, 32 were selected purposely by the recommendation of the local elders due to their long practice in providing services related to traditional herbal medicines. Whereas, 48 were selected purposely by the researchers.

\section{Data collection}

Ethnobotanical data collections were made through semi-structured questionnaire supported by field observation. The questionnaire was written in English version that was translated to local language (Oromiffa). Group discussions were made with key informants for cross-checking and verifying the information that have been gathered from individuals, and information which joined common understandings considered as relevant otherwise discarded. The collected specimens of medicinal plants were coded with vernacular names, pressed, dried and taken to botanical identification by botany specialists at national Herbarium of Addis Ababa University, College of Natural Science, Department of Plant Biology and Biodiversity. While collecting the medicinal plants, local name, general description of the plants, plant parts used, methods of preparation, routes of administration, aliments to be treated, and demographics parameters of respondents and source of knowledge were properly documented.

\section{Data analysis and management}

Collected ethno-botanical data were entered into Microsoft Excel spread sheet and analyzed using SPSS 20 software version and summarized using descriptive statistical methods such as frequency and percentages.

\section{Fidelity value}

Fidelity Level (FL), the percentage of informants claiming on the use of a certain plant for the same major purpose was calculated for the most frequently reported diseases or ailments as described by Alexiades (1996). 
$\mathrm{FL}=\mathrm{Ip} / \mathrm{Iu} \mathrm{X} 100$

Where

FL =Fidelity Level

Ip $=$ the number of informants that claim a use of a plant species to treat a particular disease

$\mathrm{Iu}=$ the number of informants that use the plants as a medicine to treat any given disease

\section{Preference ranking}

Preference ranking was also computed using fifteen key informants to assess the most effective medicinal plant species used for treating the most prevalent livestock aliments reported in the area. For this purpose, key informants were selected and asked to assign use values ( $5=$ best, $4=$ very good, 3=good, $2=$ less used and 1=least used) to each species. The values given to each medicinal plant were summed and ranked according to Martin (1995) and Cotton (1996).

\section{Results}

\section{Demographics of the respondents}

A total of 80 respondents were interviewed based on their willingness to share their indigenous knowledge on ethno-veterinary medicine. Of these respondents, the majority of them were male, $63(78.8 \%)$ and the remained, $17(21.25 \%)$ were females. The age of the respondents was ranged from 17 to 80 years, but their knowledge on medicinal plants was varied. In comparison of educational status of the respondents, non-educated respondents handled much knowledge of traditional medicine than educated one (Table 1).

\section{Inheriting knowledge of medicinal plants}

The result of this study disclosed that most of the informants $68.75 \%(55 / 80)$ have indigenous knowledge on herbal medicine, whereas the rest $31.25 \%$ (25/80) have no any indigenous knowledge on ethno-veterinary medicine. Accordingly, majority of the respondents (90.91\%) acquired the knowledge from their parents, $5.46 \%$ got by asking local herbalists and the rest (3.64\%) by trial and error on their own animals. Transfer of ethnoveterinary knowledge mostly follows vertical transfer to the most selected family member orally with great secrecy (Table 1). 
Table 1. Demography of the respondents and sources of endogenous knowledge on ethno-veterinary medicine in the study area.

\begin{tabular}{lccc}
\hline Parameters & Respondents & $\begin{array}{l}\text { Have Ethno-veterinary } \\
\text { Knowledge }\end{array}$ & $\begin{array}{l}\text { Percent } \\
\text { (\%) }\end{array}$ \\
\hline Sex & & 78 & 76.2 \\
$\quad$ Male & 63 & 17 & 41.2 \\
$\quad$ Female & 17 & & 16.7 \\
Age & & 1 & 48.4 \\
$\quad<20$ & 6 & 15 & 90.7 \\
$20-40$ & 31 & 39 & 88.2 \\
$>40$ & 43 & & 76.0 \\
Educational level & & 30 & 35.4 \\
$\quad$ Illiterate & 34 & 19 & - \\
$\quad$ Elementary & 25 & 6 & 90.9 \\
High school & 17 & - & 5.5 \\
$\quad$ Diploma \&above & 4 & & 3.6 \\
Inheriting knowledge & & 50 & \\
$\quad$ From Parents & 55 & 3 & 2 \\
Asking local herbalists & 55 & & \\
$\quad$ Through trial error & 55 & &
\end{tabular}

Identified Medicinal Plants for Treatment of Livestock Ailments in Wolmera district

This study documented 25 medicinal plant species in 22 families as useful in traditionally managing fifteen different livestock aliments in Wolmera district. Some species were recorded as being used for more than one purpose. Among the recorded species, Selanecio gigas (Votke) C. Jeffrey, Allium sativum L.,Rumex nepalensis Spreng, Capsicum annuum L. and Ferula communis $L$. were the most popular plants used to make traditional medicines in the treatment of more than one livestock aliments. Further investigation on the families has shown that families Asteraceae, Euphorbiacea, Solonaceae and Polygonaceae were represented by 2 species each. The remaining (18 families) were represented by single plant species (Table 2).

\section{Medicinal Plant Parts Used, Method of Preparation and Routes of Administration to Treat Livestock Ailments}

As shown in table 3, herbalist in Wolmera district used leaf, fruits, stems, 
seeds and roots of medicinal plants to treat different animal aliments; and leaf $(68 \%)$ was found to be the most familiar plant part for remedy preparations to treat blackleg, anthrax, bloat and ecto and endo-parasites. Different methods of ethnoveterinary medicinal plant preparations were also reported from identified plant parts. However, concoction (60\%) followed by powdering $(28 \%)$ were found to be the most frequently used methods of preparation (Table 3).

The herbal drugs following preparation were reported to be administered through different routes. The routes and method of applications varies with the type of disease to be treated and the actual sites of the disease. However, the dominant route of administration was oral (80\%) followed by topical (16\%) and nasal (4\%) (Table 3). The dose regime was generally dependent on the degree and duration of the ailment, age, size and body condition of the animals. Various house hold utensils were used to determine the dose of the local plant medicines (Figure 2). 


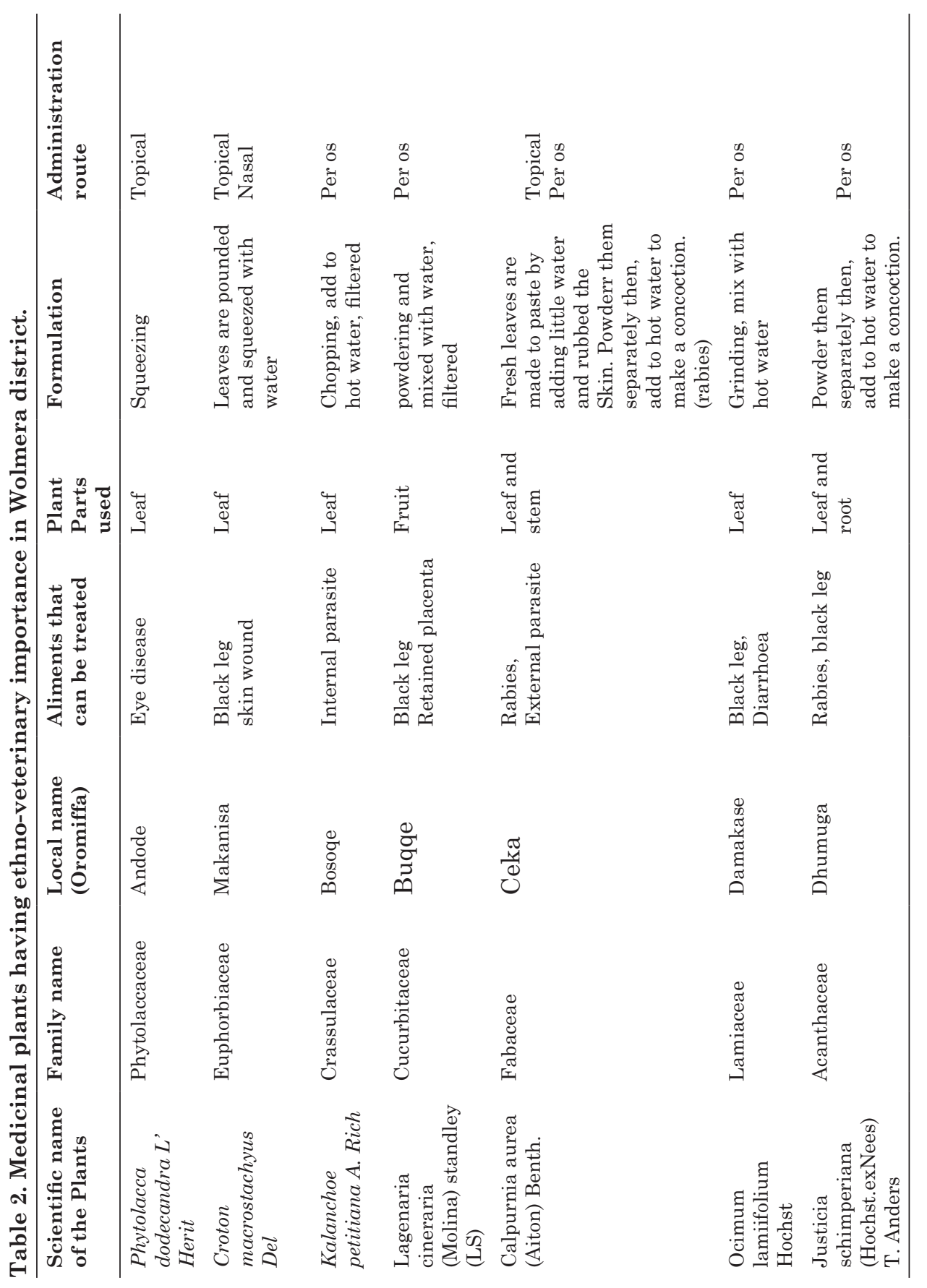




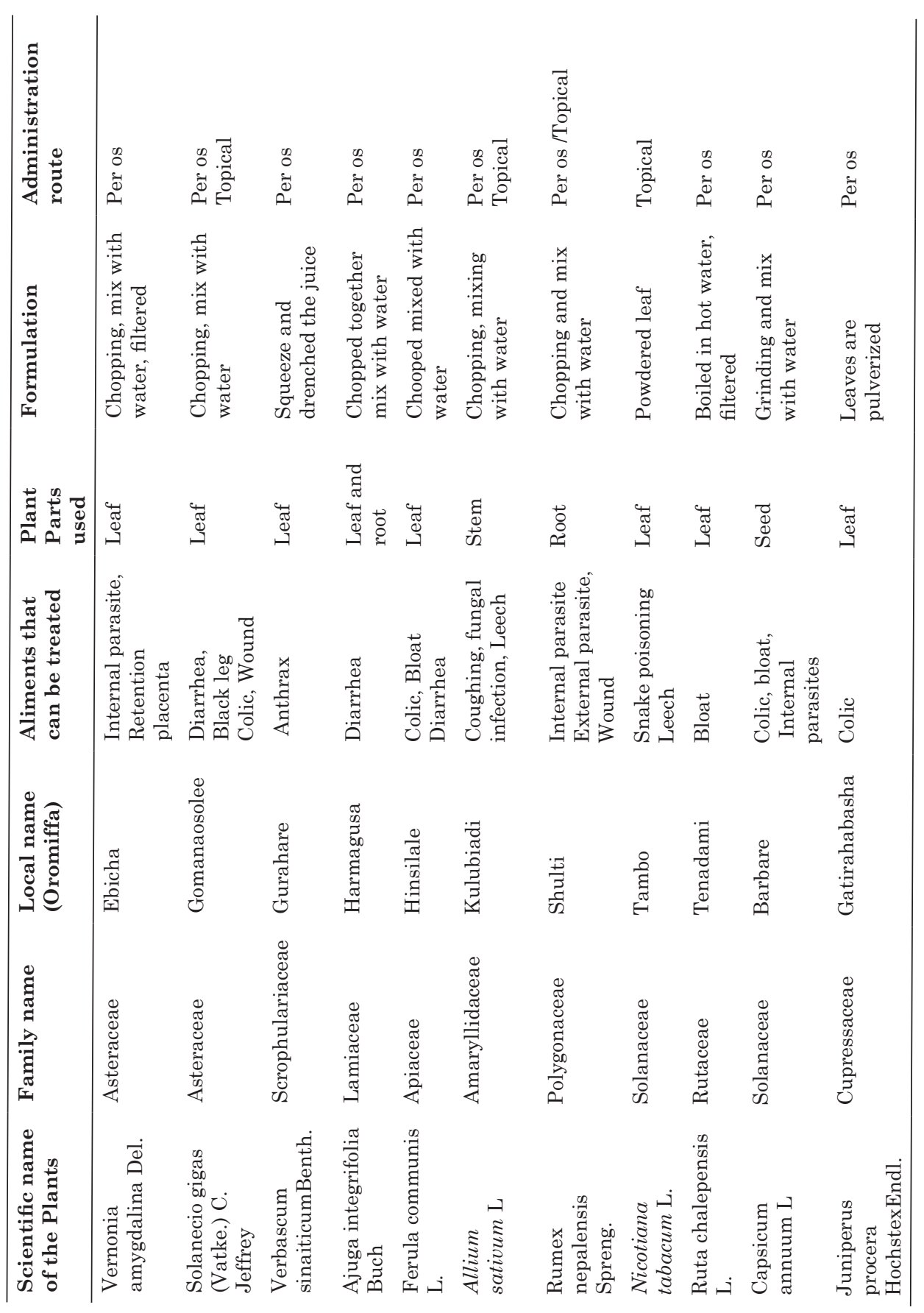




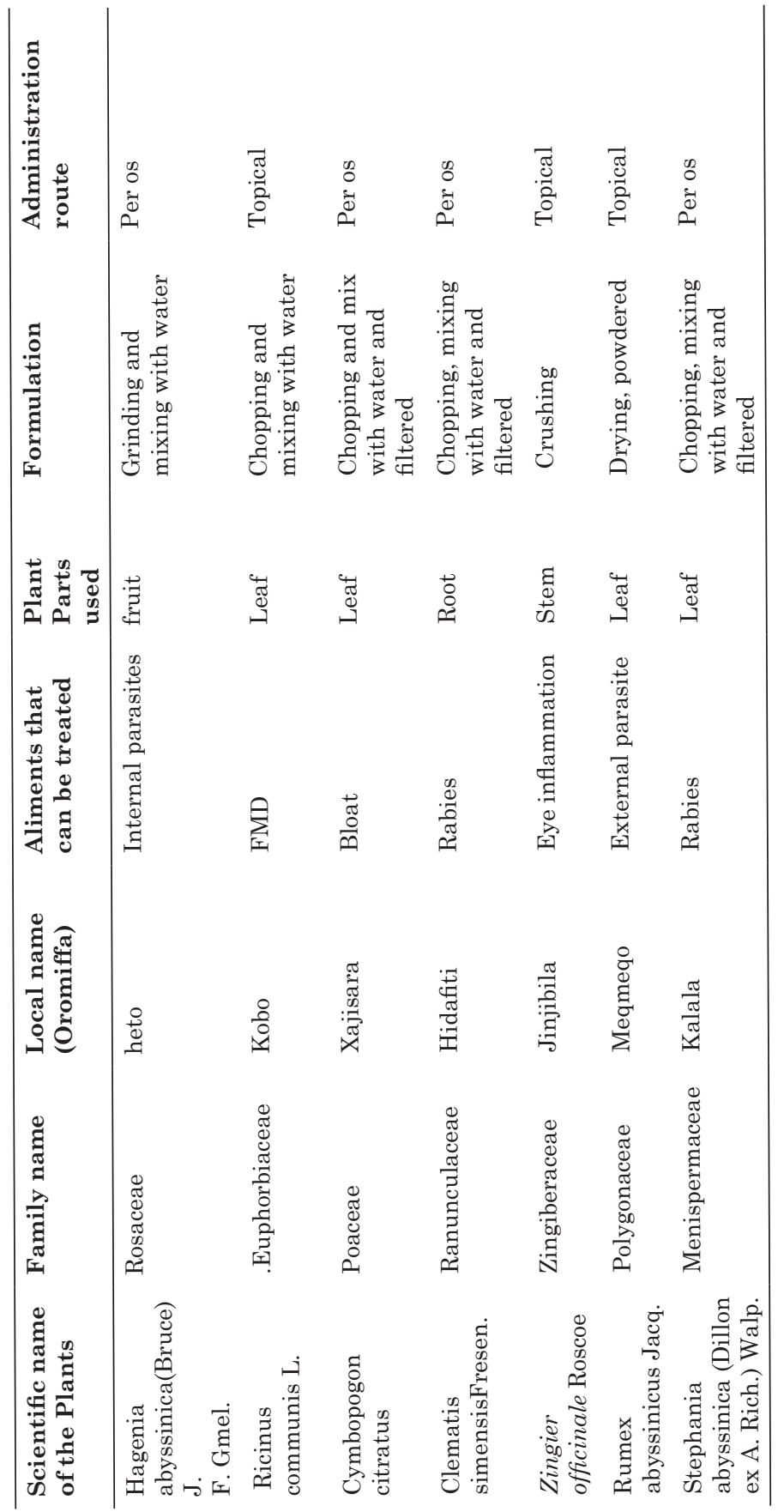


Table 3. Summary of plant part(s) used, formulation and routes of administration of medicinal plant in the study area.

\begin{tabular}{|c|c|c|}
\hline Parameters & Frequency & Percent $(\%)(n=25)$ \\
\hline \multicolumn{3}{|c|}{ Plant parts used } \\
\hline Leaf & 17 & 68 \\
\hline Stem & 4 & 16 \\
\hline Root & 2 & 8 \\
\hline Seed & 1 & 4 \\
\hline Fruit & 1 & 4 \\
\hline \multicolumn{3}{|l|}{ Formulation } \\
\hline Concoction & 15 & 60 \\
\hline Squeezing & 3 & 12 \\
\hline Crushing & 7 & 28 \\
\hline \multicolumn{3}{|c|}{ Routes of administration } \\
\hline Oral & 20 & 80 \\
\hline Topical & 4 & 16 \\
\hline Nasal & 1 & 4 \\
\hline
\end{tabular}

Figure 2. Different house hold utensils used to measure plant remedies: $\mathrm{A}=$ Ladle, $\mathrm{B}=$ Spoon, $\mathrm{C}=$ water glass, $\mathrm{D}=$ Plastic Water container, $\mathrm{E}=$ horn cup, $\mathrm{F}=$ local beer utensil 


\section{Relative healing potential of medicinal plants}

Capsicum annuum showed highest FL value (82.2\%) for the treatment of bloat and under the gastrointestinal therapeutic category, highest fidelity level value was recorded for Ocimum lamiifolium Hochst (79.3\%). Calpurnia aurea (Aiton) Benth was also showed high healing potential against external parasites (75\%) as shown in Table 4.

\section{Preference Ranking of Ethno-veterinary Plants}

Preference ranking of five medicinal plants that were reported as an effective treatment for internal parasite, which is the most common disease in the study area was conducted after selecting 15 key informants. Hagenia abyssinica (Bruce) J. F. Gmel (64\%), followed by Vernonia amygdalina Del (61\%) was the most preferred plant species for the treatment of internal parasite in the study district (Table5).

Table 4. Fidelity level value of medicinal plants commonly reported against a given veterinary ailment category.

\begin{tabular}{llllc}
\hline Medicinal plant species & $\begin{array}{l}\text { Therapeutic } \\
\text { category }\end{array}$ & Ip & Iu & $\begin{array}{l}\text { FL value } \\
\text { (\%) }\end{array}$ \\
\hline Croton macrostachyus Del & Wound & 23 & 35 & 65.7 \\
Capsicum annuum L & bloat & 23 & 28 & 82.2 \\
Rumex nepalensis Spreng & Internal parasite & 13 & 30 & 43.3 \\
$\begin{array}{l}\text { Lagenariasiceraria(Molina) standley } \\
\text { (LS) }\end{array}$ & Retained placenta & 20 & 31 & 64.5 \\
$\begin{array}{l}\text { Nicotiana tabacum L. } \\
\text { Allium sativum L }\end{array}$ & Leech & 26 & 38 & 68.4 \\
$\begin{array}{l}\text { Ocimumlamiifolium Hochst } \\
\text { Calpurnia aurea (Aiton) Benth }\end{array}$ & Respiratory disease & 12 & 28 & 42.8 \\
$\begin{array}{l}\text { Ip = the number of informants that claim a use of a plant species to treat a particular disease, Iu =the number } \\
\text { of informants that use the plants as a medicine to treat any given disease, FL= Fidelity Level }\end{array}$
\end{tabular}




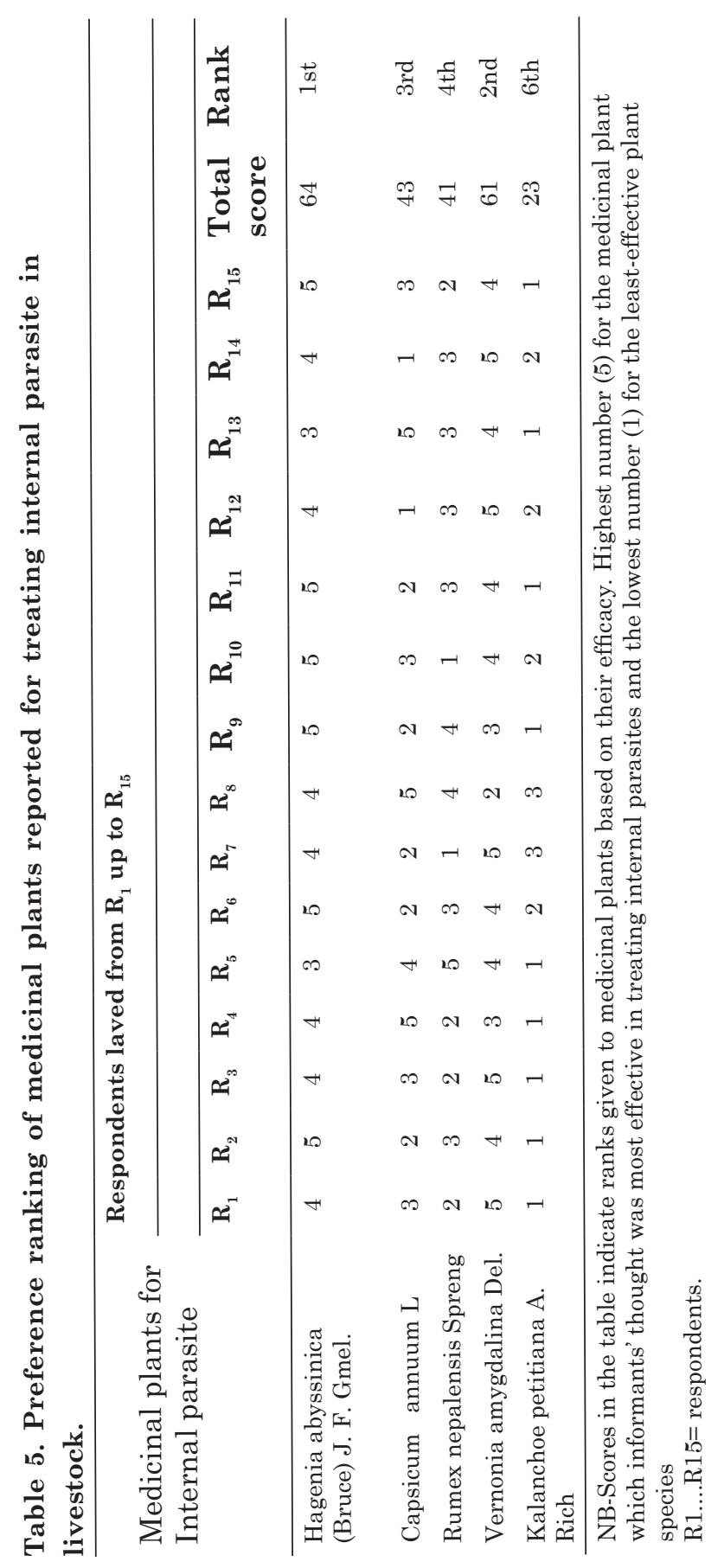

Ethiop. Vet. J., 2019, 23 (1), 111-130 


\section{Discussion}

The present study was conducted in Wolmera district of Oromia region, Ethiopia from November 2016 to March 2017 to document indigenous knowledge of the communities on Ethno-veterinary medicine. A total of 80 respondents were interviewed based on their willingness to participate in the survey. Of these respondents, only $68.75 \%$ had ethno-veterinary knowledge; and most of them were males. The result is in line with studies conducted previously in different parts of Ethiopia such as in Borena pastoralist area (Sori et al., 2004), in Jimma zone (Yigezu et al., 2014), in Ankober,North Shoa zone (Lulekal et $a l ., 2014)$ and elsewhere in creator Giyai municipality, South Africa (Luseba and Van Der Merwe, 2006) and in North western Yunnan, China (Shen et al., 2010). This similarity may be due to high degree of secrecy on passing indigenous knowledge on medicinal plants within the family circle only to sons; and could also be related with the local attitude of societies that restricts female to stay home just only for limited activities such as to look after babies and giving attention to the work performed in the home rather than reacting with outside environment.

In line with this study, other studies have reported that the highest medicinal plant knowledge is developed as the age of the herbalists increased (Yirga et al., 2012; Tamiru et al., 2013). This may be due to the fact that indigenous knowledge is built with years of experience and might also be the herbalist passed the secret to selected members of the family especially to their elder son when his age become above 40 years.

In this study, 25 species of medicinal plants belong to 22 families were identified and documented for treating 15 types of livestock aliments in study area. Studies conducted previously in different parts of Ethiopia identified and documented different plant species having value in Ethno-veterinary Medicine. Viz, 83 plant species in Southern Tigray (Giday and Ameni,2003), 43 species in Borona pastoralist area (Sori et al., 2004), 72 species in Wonago district, Southern Ethiopia (Mesfin et al.,2009), 22 species in Seharti-Samre district (Yirga et al., 2012),74 species in Jimma Zone (Yigezu et al., 2014),51 species in Ankober, North Shoa (Lulekal et al.,2014) and 24 species in Amaro special district (Tekele, 2015). These identified and documented medicinal plant species were used for treating fifteen to thirty-seven livestock aliments in each study sites. Overall, our survey and works done previously in different parts 
of Ethiopia have shown that the country is rich in medicinal plants and fairly distributed throughout its regions.

Among medicinal plant species reported in this study, 9 species in Horogudru districts (Tadesse and Dereje, 2015), 6 species in South Ethiopia (Romha et al.,2015), 2 in central Kenya (Njoroge and Bussmann, 2006), 3 in Marajó Island, Brazil (Monteiro et al.,2011) and 3 in central India (Verma, 2014) were reported to treat almost similar livestock aliments. All these findings suggest that traditional ethno-veterinary knowledge widely used in elsewhere in the world and there might be increases inclination of people to depend on such practices because it is considered equivalently effective to modern cares, and moreover, cheap and easily available in their environments (Yigezu et al.,2014).

Some of the medicinal plants reported were also described in other surveys to treat similar diseases. Vernonia amygdalina Del. And Agugain tergrifolia F.Gmel( Tekele, 2015) were used to treat internal parasites. Also, Capsium annuum $L$ and Zingiber officinale Roscoe(Lulekal et al., 2014; Tadesse and Derje, 2015) were used to treat bloat in Cattle, Zingiber officinale Roscoe (Yigezu et al.,2014) for conjunctivitis, Justicica schimperiana (Hochst.exNees) T.anders (Tadesse and Derje, 2015) for rabies, Nicotiana tabacum L. (Yigezu et al., 2014; Romha et al.,2015; Takele, 2015 ) was used to treat snake bite and leech and Croton macrostachyus Del. and Calpurnia aurea (Aiton) Benth (Lulekal et al., 2014) also reported to treat wound and tick infestation respectively. Medicinal plants that were reported by different informants and communities with the same therapeutic indications represent traces of true efficacy (Giday et al., 2009).

Alike present study, leafy part of the plants rank first, among the various plant parts(stems rots and seeds) used for treatment of various diseases of the livestock in other studies at different parts of Ethiopia (Tamiru et al., 2013; Yigezu et al., 2014; Romha et al., 2015; Tekele, 2015), in India (Verma, 2014), in Brazil (Monteiro et al.,2011), in Pakistan (Deeba et al., 2009) and in Kenya (Njoroge and Bussmann, 2006); however, in contrast to our study, Lulekal et al., (2015), Mesfin et al.(2009) and Tabuti et al. (2003) have reported that root is as the most used part in their studies. This difference could be as the pharmaceutical value and concentration of active ingredients in each plant varied depending on climatic and geographical factors, soil type, and difference in endogenous knowledge in the communities; and might be also the types of medicinal plant species found in the study areas. However, harvesting of leaves compared to 
harvesting of stems and roots has a less negative impact on the survival and sustainable utilization of useful medicinal plants in future perspective (Yigezu et al., 2014).

Herbalists in the study area were used a variety way to prepare their plant remedies such as concoction, crushing/powdering and squeezing and administered the prepared remedies per os or applied topically. These findings were concurred with the reports of Yigezu et al. (2014) in Jimma zone, Mesfin et al. (2009) in Wonago, Ethiopia, Deeba et al. (2009) in Pakistan, Njoroge and Bussmann (2006) in Kenya and Shen et al. (2010) in Nu Village of western China. These methods of preparation and routes of administration might be related to usage of different solvents mainly water as vehicle system; and could be also considered as rapid physiological reaction with the causative agents and increase the curative power of the medicinal plant remedies.

Determination of dose of plant medicine was determined by severity and duration of ailments, body size and age of the patients. However, there were variations in unit of measurement of plant remedies. Most of the time, doses in the study area were determined by using different house hold utensils like water glasses, ladles, horn cups, spoons and plastic containers. On the other hand, lack of precision and standardization has been reported as a drawback of remedy preparation from medicinal plants. Similar findings were reported in Ethiopia and elsewhere in the world (Yineger et al., 2008; Deeba et al., 2009; Monteiro et al., 2011; Lulekal et al., 2014; Romha et al., 2015).

Healing potential for some medicinal plants was estimated using Fidelity level (FL). Accordingly, Capsicum annuum L. (82.2\%), followed by Calpurnia aurea (Aiton) (75\%) were the plants having the highest FL value, for their use to treat bloat and external parasites, respectively. Similar findings have been reported in other studies (Lulekal et al., 2014; Romha et al., 2015). Plants scoring higher FL values are thought to have better potency as compared to plants with less FL values (Trotter and Logan 1986). On the other hand, Lulekal et al. (2013) recommended for further chemical screening those plants with high FL values.

Hagenia abyssinica (Bruce) J. F. Gmel and Vernonia amygdalina Del. were the most preferred medicinal plant species to treat internal parasites, the most prevalent disease in the area. This might be attributed to the presence of bioactive compounds against different internal parasitic species 


\section{Conclusion and Recommendation}

Ethno-veterinary practices significantly play a major role in livestock health care as an alternative or integral part of modern veterinary practices especially in marginal areas where modern veterinary coverage is lacking. In this survey, about 25 medicinal plant species belong to 22 families were identified and documented. The people in the study district have ample ethno- veterinary knowledge in treatment of livestock aliments of different origins. However, the efficacy and the toxicity level of each medicinal plant species were not well known. Therefore, we strongly recommended for detail scientific and pharmacological evaluations (efficacy, safety, mode of delivery and dosage) of the identified plant species in future use.

\section{Acknowledgments}

We are thankful to the people of the Wolmera district, Oromia Region for their participation in this study and for sharing their valuable knowledge and experience. We are also grateful to national Herbarium of Addis Ababa University staffs for their valuable help in plant identification.

\section{Conflict of interest}

There is no conflict of interest to declare

\section{References}

Alexiades, M.,1996. Collecting ethnobotanical data: An introduction to basic concepts and techniques. Selected Guideline for Ethnobotanical Research: A Field Manual. Edited by: Alexiades M, Sheldon JW., Bronx, New York: The New York Botanical Garden.

Briggs, P., 2002. Ethiopia, The Bradt Travel Guide, $3^{\text {rd }}$ edition, Chalfont St Peters: Bradt, p. 481.

CSA (Central Statistical Agency). 2015. Agricultural sample survey of 2014/2015, report on livestock and livestock characteristics, Addis Ababa, statistical bulletin, V II, p. 40.

Cotton, C.M., 1996. Ethno-botany: Principles and Applications. John Wiley and Sons Ltd. Chichester, England. 
Deeba, F., Muhammad, G., Iqbal, Z. and Hussain, I., 2009. Survey of ethno-veterinary practices used for different ailments in dairy animals in peri-urban areas of Faisalabad (Pakistan). Int. J. Agro. Biol.,11(5), 535-541.

Endashaw, B.,2007. Study on actual situation of medicinal plants in Ethiopia, Prepared for JAICAF (Japan Association for International Collaboration of Agriculture and Forestry) pp.1-66.

Giday, M. and Teklehaymanot, T., 2013. Ethnobotanical study of plants used in management of livestock health problems by Afar people of Ada'ar district, Afar regional state, Ethiopia. J. Ethnobiol. Ethnomed.,9,1-8

Giday, M., and Ameni, G., 2003. An ethnobotanical survey on plants of veterinary importance in two districts of Southern Tigray, Northern Ethiopia. Ethiop. J. Sci., 26 (3), 123-136.

Giday, M., Asfaw, Z. and Woldu, Z., 2009. Medicinal plants of the Meinit ethnic group of Ethiopia. An ethnobotanical study. J. Ethnopharmacol.,124(3), 513-521.

Hunde, D., Asfaw, Z., Kelbessa, E. 2004. Use and management of ethnoveterinary medicinal plants by indigenous people in 'Boosat', Welenchetti area, Ethiopia. Ethiop. J. Biolo. Sci., 3,113-132.

Kalayou, S., Haileselassie, M., Gebre-egziabher, G., Tikue, T., Sahle, S., Taddele, H., and Ghezu, M., 2012. In-vitro antimicrobial activity screening of some ethnoveterinary medicinal plants traditionally used against mastitis, wound and gastrointestinal tract complication in Tigray Region, Ethiopia. Asian Pac. J. Trop. Biomed.,2, 516-522.

Kaur, R., Kapoor, K. and Kaur, H., 2011. Plants as a source of anticancer agents. J. Nat. Prod. Plant Resour.,1, 119-24.

Kebu, B., Ensermu, K.and Zemede, A., 2004. Indigenous medicinal utilization, management and threats in Fentale area, Eastern Shewa, Ethiopia. Ethiop. J. Biolo. Sci., $3(1), 37-58$.

Khan, M. and Hussain. M., 2012. Ethno-Veterinary Medicinal Uses of Plants of Poonch Valley Azad Kashmir. Pak. J. Weed. Sci. Res., 18,495-507.

Lulekal, E., Asfaw. Z., Kelbessa. E., and Van Damme. P., 2014. Ethnoveterinary plants of Ankober District, North Shewa Zone, Amhara Region, Ethiopia. J. Ethnobiol. Ethnomed., 10(21), 2.

Luseba, D., Van Der Merwe, D., (2006). Ethnoveterinary medicine practices among Tsonga speaking people of South Africa. Onderstepoort J. Vet. Res., 73, 115-122.

Martin, J., 996. Ethnobotany, A 'people and Plants' Conservation Manual, Chapman and Hall, pp.268. 
Mesfin, F., Demissew, S., Teklehaymanot, T., 2009. An ethnobotanical study of medicinal plants in Wonago Woreda, SNNPR, Ethiopia. J. Ethnobiol.Ethnomed., 5(28) .https://doi.org/10.1186/1746-4269-5-28.

Monteiro, M. V., Bevilaqua, C. M., Palha, M., Braga, R. R., Schwanke, K., Rodrigues, S. T.and Lameira, O.A., 2011. Ethnoveterinary knowledge of the inhabitants of Marajó Island, Eastern Amazonia, Brazil. Acta Amaz., 41(2), 36-47.

Njoroge, G. N.and Bussmann, R. W., 2006. Herbal usage and informant consensus in ethnoveterinary management of cattle diseases among the Kikuyus (Central Kenya). J. Ethnopharmacol., 108(3). 332-339. doi:10.1016/j.jep.2006.05.031.

Romha, G., Dejene, T., Telila, L.and Bekele, D. 2015. Ethnoveterinary medicinal plants: Preparation and application methods by traditional healers in selected districts of southern Ethiopia. Vet. World., 8 (5), 674-684.

Shen, S., Qian. J., Ren, J., 2010. Ethnoveterinary plant remedies used by Nu people in NW Yunnan of China. J. Ethnobiol. Ethnomed., 6 (24), 1186-1124.

Somvanshi, R., 2006. Veterinary medicine and animal keeping in ancient India. Asian Agri-his., 10(1),133-146.

Sori, T, Bekana, M., Adugna, G., .and Kelbessa, E., 2004. Medicinal plants in the ethnoveterinary practices of Borana Pastoralists, Southern Ethiopia. Int. J. Appl. Res. Vet. Med., 3(2), 220-225.

Tabuti, J. R, DhillionS. S. and Lye, K.A., 2003. Ethno-veterinary medicines for cattle (Bos indicus) in Bulamogi county Uganda: plant species and mode of use. J. Ethnopharmacol., 88,279-286.

Tadesse, B., and Dereje, A., 2015. Survey of ethno-veterinary medicinal plants at selected Horro Gudurru Districts, Western Ethiopia. Afr. J. plant sci., 9(3),185-192.

Tafara, M., and Taona, B., 2004. Ethno-veterinary medicine: A potential alternative to orthodox animal health delivery in Zimbabwe. Int. J. Vet. Med., 2 (4),269-273.

Tekele, Y. 2015. Study on Ethno-veterinary Practices in Amaro Special District Southern Ethiopia. Med. Aromat. Plants, 4(2), 1-8.

Tamiru, F., Waktole, T., Ejigu, K., Gizaw, D., Kumar. R. and Sorsa, M., 2013. Ethnoknowledge of plants used in veterinary practices in Dabo Hana District, West Ethiopia. J. Med. Plants Res., 7(40), 2960-2971.

Trotter, R. T. and Logan, M. H., 1986. Informants consensus: a new approach for identifying potentially effective medicinal plants. Plants in Indigenous Medicine and Diet. Edited by: Etkin NL, Bedford H., New York: Redgrave Publishing Company.

Vander, M., Swan, G., Botha, C.J.,2001. Ethno-veterinary medicinal plants in Northwest province of South Africa. J. S. Afr. Vet. Assoc., 72(4),189-196.

Ethiop. Vet. J., 2019, 23 (1), 111-130 
Verma, R.K., 2014. An ethnobotanical study of plants used for the treatment of livestock diseases in Tikamgarh District of Bundelkhand Central India. Asian Pac. J. Trop. Biomed., 4 (Suppl 1): S460-7. doi:10.12980/APJTB.4.2014C1067.

Yigezu. Y., Berihun., D.and Yenet. W., 2014. Ethnoveterinary medicines in four districts of Jimma zone, Ethiopia: cross sectional survey for plant species and mode of use. BMC Vet. Res., 10(76). doi.org/10.1186/1746-6148-10-76.

Yinegar, H., Kelbessa, E., Bekele, T. and Lulekal, E., 2007. Ethnoveterinary medicinal plants in Bale Mountains National Park, Ethiopia. J. Ethnopharmacol.,112 (1), 55-70.

Yineger, H., Yewhalaw, D. and Teketay, D., 2008. Plants of veterinary importance in Southwestern Ethiopia, The case of Gilgel Ghibe area. Forest Trees Livelihoods, 18 (2), 165-181.

Yirga, G., Teferi, M., Brhane, G., .and Amare, S., 2012. Plants used in ethnoveterinary practices in Medebay-Zana District, Northern Ethiopia. J. Med. Plants Res.,6(3),433-438. 